\title{
UPAYA MENINGKATKAN PROSOSIAL MELALUI BIMBINGAN KELOMPOK PADA SISWA KELAS IX F MTS NEGERI BONANG
}

\author{
Elsye Irianti \\ MTs Negeri 5 Demak Jawa Tengah \\ E-mail: elsyemtsnbonang@gmail.com
}

\begin{abstract}
Abstrak
Siswa MTs menumbuhkan sikap prososial yang ditandai dengan kemampuan untuk mau menolong terhadap sesama. Berdasarkan studi pendahuluan pada siswa MTs Negeri Bonang ditemukan bahwa sikap prososial siswa kategori rendah. Penelitian ini bertujuan dapat meningkatkan prososial melalui layanan bimbingan kelompok pada siswa kelas IX F semester 2 MTs Negeri Bonang. Metode penelitian dilakukan dengan metode Penelitian Tindakan Bimbingan Konseling. Berdasarkan hasil pemberian layanan pada siklus I yang oleh peneliti diawali dengan perencaaan dilanjutkan dengan tindakan, observasi dan refleksi. Peneliti melalui bimbingan kelompok, ternyata hasil yang dicapai dalam bimbingan kelompok pada siklus I, beberapa siswa masih terlihat kurang antusias dan kurang memahami materi yang di berikan dalam layanan. Adapun dengan siklus II, siswa mengikuti kegiatan layanan bimbingan kelompok sangat antusias. Pemberian layanan bimbingan kelompok melalui dua siklus ini mengalami perubahan yang signifikan. Upaya yang perlu dilakukan untuk membantu siswa meningkatkan sikap prososial adalah dengan mengoptimalkan pelaksanaan layanan bimbingan kelompok. Untuk itu disarankan pada guru bimbingan dan konseling sebagai praktisi dilapangan untuk menggunakan model bimbingan kelompok dapat dijadikan salah satu alternative dalam memaksimalkan mutu pelayanan bimbingan kelompok.
\end{abstract}

Kata kunci: prososial, bimbingan kelompok, siswa MTs

\begin{abstract}
MTs students foster prosocial attitudes characterized by the ability to be willing to help others. Based on a preliminary study on MTs Negeri Bonang students it was found that the prosocial attitudes of students were in the low category. This study aims to improve prosocial through group guidance services for students of class IX F semester 2 MTs Negeri Bonang. The research method was conducted with the Guidance Counseling Action Research method. Based on the results of service delivery in the first cycle which the researchers began with the planning continued with action, observation and reflection. Researchers through group guidance, it turns out the results achieved in group guidance in the first cycle, some students still look less enthusiastic and less understanding of the material provided in the service. As for the second cycle, students taking part in group guidance service activities were very enthusiastic. The provision of group guidance services through these two cycles experienced significant changes. Efforts need to be made to help students improve prosocial attitudes is to optimize the implementation of group guidance services. For this reason, it is recommended that guidance and counseling teachers as practitioners in the field to use the group guidance model can be used as an alternative in maximizing the quality of group guidance services.
\end{abstract}

Keywords: prosocial, group guidance, MTs students

Info Artikel

Diterima Oktober 2019, disetujui November 2019, diterbitkan Desember 2019

Dipublikasikan Oleh: Program Studi Bimbingan dan Konseling 


\section{PENDAHULUAN}

Kegiatan layanan Bimbingan Konseling merupakan kegiatan untuk memberikan bantuan kepada individu agar mampu memahami dan menerima diri dan lingkungannya, mengarahkan diri, dan menyesuaikan diri secara positif dan konstruktif terhadap tuntutan norma kehidupan ( agama dan budaya) sehingga mencapai kehidupan yang bermakna (berbahagia, baik secara personal maupun sosial).

Anak sebagai individu yang sedang berkembang seluruh aspek kepribadiannya. Kepribadian individu sangat kompleks, terdiri banyak aspek yang saling berinteraksi, bukan saja antar aspek tetapi antara aspek-aspek dengan faktor-faktor lingkungan. Baik aspek kepribadian individu maupun aspek lingkungan selalu berubah dan perubahannya sangat dinamis. Kepribadian individu mencakup aspek fisik, intelek, sosial dan afektif. Aspek fisik meliputi tinggi dan berat badan, pancaindra, postur tubuh, kekuatan, ketahanan, ketrampilan fisik, hormon dan lain-lain. Aspek intelek atau kognitif mencakup kecerdasan atau inteligensi, bakat-bakat khusus serta berbagai bentuk kecakapan. Aspek sosial meliputi berbagai kecakapan dan keterampilan berhubungan dengan orang, seperti kecakapan berbahasa (berkomunikasi), bekerjasama, memimpin dan aktivitas-aktivitas social lainnya. Aspek afektif terdiri atas sikap, minat emosi, perasaan, motivasi, moral, keindahan dan lain-lain.

Aspek-aspek tersebut secara berkala terus berubah (berkembang) dan dalam perkembangannya selalu berinteraksi satu sama lain membentuk satu kesatuan atau integrasi. Integrasi ini bisa terjadi secara alamiah tetapi kebanyakan berlangsung melalui proses belajar, baik belajar atas usaha individu sendiri maupun bantuan orang lain. Proses pengembangan integritas kepribadian tidak selalu berjalan mulus, seringkali mengalami hambatan. Hambatan ini akan semakin besar dirasakan individu apabila mendapatkan pengaruh-pengaruh yang kurang baik dari lingkungan.

Peranan lingkungan yang baik pada anak, akan berdampak positif pada anak. sehingga anak cenderung lebih sosial dan memiliki penyesuaian diri yang baik, serta dapat memungkinkan untuk munculnya perilaku prososial yang semakin berkembang. Perilaku prososial merupakan salah satu bentuk perilaku yang muncul dalam kontak sosial, sehingga perilaku prososial adalah tindakan yang dilakukan atau direncanakan untuk menolong orang lain tanpa mempedulikan motif-motif si penolong. Tindakan menolong sepenuhnya dimotivasi oleh kepentingan sendiri tanpa mengharapkan sesuatu untuk dirinya.

Perilaku prososial merupakan perilaku yang ideal dan dianggap bisa menciptakan suatu tatanan hidup bermasyarakat yang bersih, langgeng, dan sehat. Peranan lingkungan sosial (keluarga, sekolah maupun masyarakat) yang baik pada anak, akan berdampak positif pada anak sehingga anak cenderung lebih sosial dan memiliki penyesuaian diri yang baik. Melihat hal yang demikian, peranan sekolah sebagai tempat untuk mendidik dan mengajar sangat diperlukan, selain pendidikan di lingkungan keluarga. Dalam hal ini guru adalah orang yang paling tepat untuk mewujudkan suatu kondisi dalam memenuhi kebutuhan siswa, sebab guru adalah orang pertama dan utama yang selalu berkomunikasi dengan siswa di kelas atau diluar kelas. Peran guru sebagai pendidik, pengajar dan pembimbing, dalam Undang-Undang Guru dan Dosen No. 14 Tahun 2005, disebutkan bahwa "Guru adalah profesi yang mempunyai tugas sebagai pendidik, pengajar dan pembimbing”. Peran guru sebagai pembimbing merupakan suatu implementasi dari suatu kompetensi, melalui kemampuan guru dalam menjalankan tugasnya secara profesional yang memiliki kemampuan dalam mengembangkan kompetensi siswa seoptimal mungkin. 
Pendidikan di sekolah itulah siswa mulai belajar mengembangkan aspek kepribadian dan kemampuan sosial yang disesuaikan dengan perkembangan individu secara wajar dan alamiah. Melalui pembelajaran disekolah, diharapkan tingkah laku prososial siswa baik. Dalam setting kehidupan sekolah pengembangan prososial merupakan salah satu strategi yang dapat dilakukan dalam mensikapi perkembangan yang semakin kompleks. Sehingga idealnya agar keberadaan individu dapat diterima oleh lingkungan yang semakin kompleks dan penuh tantangan maka setiap orang perlu memiliki dan mengembangkan prososial dalam kehidupannya sehari-hari. Dalam perkembangan prososial, siswa MTs menempati posisi strategis karena siswa MTs berada pada posisi masa remaja. Masa remaja secara psikologis tengah berada pada masa topan dan badai, serta mencari identitas diri yang rawan sekali mengalami konflik. Usaha adaptasi atau penyesuaian diri terhadap berbagai perubahan yang sangat kompleks menjadi hal yang tidak mudah. Kesulitan mengadakan adaptasi menyebabkan terjadi kebimbangan, kebingungan, kecemasan dan konflik-konflik eksternal yang terbuka maupun internal dalam batin sendiri yang sifatnya tertutup. Sebagai dampaknya muncul kecenderungan remaja mengembangkan pola tingkah laku yang berbeda dengan norma - norma yang umum, seperti acuh tak acuh terhadap lingkungan, berbuat semaunya sendiri demi kepentingan pribadi, kurang bertanggungjawab, mengganggu dan merugikan pihak lain.

Berita media massa sering memberitakan tentang perkelahian antar remaja. Bahkan tak jarang masalah kecil saja dapat memicu munculnya perkelahian remaja antar kelompok. Beberapa bentuk dari dampak prososial yang rendah juga berkaitan dengan perilaku pelanggaran baik yang dilakukan di sekolah, rumah maupun dimasyarakat yang tidak jarang melibatkan tindak kekerasan, atau pengrusakan terhadap benda-benda sekitar, misalnya membolos, balapan liar, berkelahi dan sebagainya.

Fakta yang sama juga terjadi di MTs Negeri Bonang, beberapa perilaku siswanya yang cenderung mengarah pada indikator prososial rendah seperti acuh tak acuh terhadap lingkungan, membolos, berbuat semaunya sendiri, mengganggu dan kurang bertanggungjawab. Sebagaimana fakta yang telah dituliskan diatas memang sungguh memprihatinkan dan perlu segera mendapat penanganan yang serius. Karena dampak yang dirasakan masyarakat akibat prososial yang rendah ini akan menimbulkan keresahan pada kehidupan bermasyarakat

Siswa yang mestinya mampu menunjukkan keluwesan dalam memilih respon terhadap setiap peristiwa yang terjadi di lingkungannya, menunjukkan inisiatifnya dan bertanggung jawab terhadap setiap perilakunya ternyata belum sepenuhnya mampu melaksanakan, sehingga semakin meresahkan jika dikaitkan dengan situasi masa depan remaja yang akan semakin kompleks dan penuh tantangan.

Sekolah mempunyai peranan atau tanggung jawab penting dalam membantu para siswa mencapai tugas perkembangannya. Sehingga sekolah seyogyanya dapat berupaya menciptakan iklim kondusif, atau kondisi yang dapat memfasilitasi siswa untk mencapai tugas perkembangan sebagai seorang remaja.

Pelayanan bimbingan dan konseling di sekolah bertujuan membantu siswa dalam pengembangkan kehidupan pribadi, kehidupan sosial, kegiatan belajar serta perencanaan dan pengembangan karir. Pelayanan BK memfasilitasi pengembangan peserta didik secara individual, kelompok dan atau klasikal sesuai dengan kebutuhan, potensi, bakat, minat, perkembangan, kondisi, serta peluang-peluang yang dimiliki. Kegiatan layanan Bimbingan Konseling merupakan kegiatan untuk memberikan 
bantuan kepada individu agar mampu memahami dan menerima diri dan lingkungannya, mengarahkan diri, dan menyesuaikan diri secara positif dan konstruktif terhadap tuntutan norma kehidupan ( agama dan budaya) sehingga mencapai kehidupan yang bermakna (berbahagia, baik secara personal maupun sosial). Salah satu pendekatan bimbingan dan konseling di sekolah di laksanakan secara kelompok.

Layanan Bimbingan kelompok merupakan bagian dari pelayanan konseling yang diberikan kepada sejumlah klien sekaligus dalam sebuah kelompok atau layanan yang diberikan dalam suasana kelompok dan dipimpin oleh konselor. Kegiatan bimbingan kelompok di sekolah merupakan kegiatan pemberian informasi kepada sekelompok siswa untuk membantu mereka menyusun rencana dan membuat keputusan yang tepat.

Layanan bimbingan kelompok membahas berbagai permasalahan umum atau topik yang menjadi keperdulian bersama para anggota kelompok. Melalui dinamika kelompok yang dibangun secara kontinyu, membahas topik-topik itu mendorong pengembangan perasaan, pikiran, persepsi, wawasan dan sikap yang menunjang diwujudkannya sikap dan tingkah laku yang lebih efektif, khususnya sikap prososial siswa tidak hanya dapat membentuk dengan pendekatan personal namun dengan pendekatan kelompok seperti layanan bimbingan kelompok akan lebih optimal karena siswa tidak akan merasa terhakimi oleh keadaannya sendiri. Anggota kelompok juga akan merasa mendapat penanganan dan informasi yang tepat untuk meningkatkan sikap khususnya sikap prososial.

Tugas pendidikan, utamanya di sekolah untuk mengembangkan kemampuan prososial siswa dengan menggunakan berbagai metode dan pendekatan. Prososial yang rendah mungkin dikarenakan belum mendapatkan layanan yang betul-betul menyentuh dan membangkitkan kesadaran siswa akan pentingnya prososial dalam kehidupan sehari-hari, khususnya dalam menciptakan iklim kelas atau sekolah yang kondusif yang sangat berpengaruh terhadap perkembangan prestasi akademik siswa.

Berdasarkan karakteristik siswa MTs yang senang berkelompok, lebih terbuka dan mau menerima masukan dari teman sebaya, maka bimbingan kelompok adalah layanan yang tepat untuk meningkatkan prososial siswa. Pelayanan bimbingan dan konseling sebagai bagian yang integral dalam penyelenggaraan sistem pendidikan di sekolah tentunya harus dapat memunculkan upaya penanganan terhadap kondisi prososial siswa saat ini. Berdasarkan uraian diatas nampaknya bimbingan kelompok sebagai sebuah layanan yang memfasilitasi berkembangnya kepribadian anggota kelompok dengan menekankan pada keterbukaan, kejujuran, tanggung jawab, empati dan kesadaran diri sendiri, merupakan salah satu pilihan yang sangat tepat untuk meningkatkan prososial siswa.

Proses yang terjadi dalam bimbingan kelompok inilah yang nantinya diharapkan dapat menjadi laboratorium nyata bagi anggota kelompok dalam meningkatkan prososial. Oleh karena itu, perlu dilaksanakan penelitian yang bertujuan untuk meningkatkan prososial siswa melalui layanan bimbingan kelompok pada siswa kelas IX F Semester 2 MTs Negeri Bonang

\section{Pengertian Bimbingan Kelompok}

Banyak para pakar bimbingan dan konseling yang memberikan definisi tentang bimbingan kelompok, diantaranya Tohirin (2008: 170) mengemukakan bahwa bimbingan kelompok merupakan suatu cara memberikan bantuan (bimbingan) kepada individu (siswa) melalui kegiatan kelompok. 
Wibowo (2005: 17) mengemukakan bahwa bimbingan kelompok adalah suatu kegiatan kelompok dimana pemimpin kelompok menyediakan informasi-informasi dan mengarahkan diskusi agar anggota kelompok menjadi lebih sosial atau membantu anggota-anggota untuk mencapai tujuan-tujuan bersama.

Winkel dan Hastuti (2010: 564) mengemukakan bahwa bimbingan kelompok merupakan salah satu pengalaman melalui pembentukan kelompok yang khas untuk keperluan layanan bimbingan. Menurut Prayitno (2004: 309) bimbingan kelompok adalah layanan bimbingan yang diberikan dalam suasana kelompok.

Dari beberapa pendapat diatas, dapat disimpulkan bahwa bimbingan kelompok adalah suatu kegiatan kelompok yang dilakukan oleh sekelompok orang dengan memanfaatkan dinamika kelompok yaitu adanya interaksi saling mengeluarkan pendapat, memberikan tanggapan, saran, dan sebagainya, dimana pemimpin kelompok menyediakan informasi-informasi yang bermanfaat agar dapat membantu individu mencapai perkembangan yang optimal.

Sedangkan dinamika kelompok adalah suasana kelompok yang hidup, agar tujuan bimbinhgan kelompok dapat tercapai dengan baik, ditandai oleh semangat kerjasama antar anggota kelompok untuk mencapai tujuan kelompok. Dalam suasana seperti itu seluruh anggota kelompok menampilkqn dan membuka diri serta memberikan sumbangan bagi kesuksesan kegiatan kelompok. Dalam kegiatan bimbingan kelompok dinamika bimbingan kelompok sengaja ditumbuhkembangkan, karena dinamika kelompok adalah hubungan interpersonal yang ditandai dengan semangat, kerja sama antar anggota kelompok, saling berbagi pengetahuan, pengalaman dan mencapai tujuan kelompok. Sedang Gibson dan Mitchell (2011: 278) bahwa dinamika kelompok mengacu pada kekuatan-kekuatan sosial dan pengoperasian yang bermain di dalam kelompok dalam waktu tertentu. Dinamika kelompok menggambarkan adanya interaksi kelompok, adanya pengaruh kepemimpinan, peran kelompok dan partisipasi anggota di dalam kelompok.

\section{Tujuan Bimbingan Kelompok}

Setiap usaha dan kegiatan yang dilakukan secara sadar, terencana, terprogram secara komprehensif, pasti ada sesuatu yang ingin dicapai.. Dalam melakukan bantuan dalam bentuk bimbingan kelompok, konselor seharusnya memahami apa yang akan dilakukan, mempersiapkan perencanaan matang sehingga mengetahui benar tujuan dan mafaat bagi para peserta didik. Untuk menunjang kemampuan konselor menjalankan kegiatan bimbingan kelompok, pembimbing atau konselor dituntut untuk mampu membentuk kelompok dan mengarahkan anggota kelompok sehingga terwujud dinamika kelompok dalam suasana interaksiantara anggota kelompok yang beas, terbuka, demokratis, konstruktif, saling mendukung, meringankan beban, menjelaskan, memberikan pencerahan, memberikan rasa nyaman,menggembirakan, membahagiakan dan mencapai tujuan bersama kelompok. memiliki wawasan yang luas dan tajam sehingga mampu mengisi, menjembatani,meningkatkan memperluas dan mensinergikan konten bahasan yang tumbuh dalam aktivitas kelompok. Konten bahasan merupakan isi atau materi yang dibahas dalam layanan bimbingan kelompok yang mencakup fakta atau data, konsep, proses, hokum, aturan, nilai, persepsi, afeksi, sikap dan tindakan baik langsung maupun tidak langsung. memiliki kemampuan berinteraksi antara personal yang hangat, nyaman, sabar, memberi kesempatan, demokratis dalam mengambil kesimpulan dan keputusan, tidak memaksakan dalam ketegasan dan kelembutan, jujur, tidak pura-pura disiplin dan kerja keras. 
Tujuan bimbingan kelompok adalah untuk memberi informasi dan data untuk mempermudah pembuatan keputusan dan tingkah laku. Selian itu, tujuan yang ingin dicapai dalam layanan bimbingan kelompok adalah pengembangan pribadi, pembahasan topik-topik atau masalah-masalah umum secara luas dan mendalam yang bermanfaat bagi anggota kelompok sehingga terhindar dari permasalahan yang berkaitan dengan topik atau masalah yang dibahas (Wibowo, 2005:18).

Winkel dan Sri Hastuti (2006:547) menyatakan bahwa tujuan layanan bimbingan kelompok adalah meningkatkan mutu atau kualitas kerja sama antar anggota dalam suatu kelompok untuk menunjang perkembangan pribadi.

Sedangkan Prayitno (2004: 2) menjelaskan tujuan bimbingan kelompok,adalah tujuan umum dan tujuan khusus. Tujuan umum kegiatan bimbingan kelompok adalah berkembangnya kemampuan sosialisasi siswa, khususnya kemampuan komunikasi peserta layanan. Secara khusus, bimbingan kelompok bertujuan untuk membahas topiktopik tertentu yang mengandung permasalahan aktual (hangat) dan menjadi perhatian peserta.

\section{Pelaksanaan Layanan Bimbingan Kelompok}

Layanan bimbingan kelompok menempuh tahap-tahap kegiatan (Tohirin. 2008:176) yaitu perencanaan, pelaksanaan, evaluasi, analisis hasil evaluasi, tindak lanjut dan laporan.

Perencanaan yang mencakup kegiatan mengidentifikasi topik yang akan dibahas dalam layanan bimbingan kelompok, membentuk kelompok. Kelompok yang terlalu kecil (misalnya hanya 2-3 orang saja) tidak efektif untuk layanan bimbingan kelompok karena kedalaman dan variasi pembahasan menjadi berkurang dan dampak layanan juga menjadi terbatas. Sebaliknya kelompok yang terlalu besarpun tidak efektif karena akan mengurangi tingkat partisipasi aktif individual dalam kelompok. Kelompok juga kurang efektif jika umlah anggotanya melebihi 10 orang. Kelompok yang ideal jumlah anggota antara 8-10 orang. menyusun jadwal kegiatan, menetapkan prosedur layanan, menetapkan fasilitas layanan dan menyiapkan kelengkapan administrasi.

Prososial adalah tindakan yang membantu atau dirancang untuk membantu orang lain, terlepas dari motif si penolong (Shelley. 2009: 457). Sedangkan menurut Baron (2005:92) tingkah laku prososial adalah suatu tindakan menolong yang menguntungkan orang lain tanpa harus menyediakan suatu keuntungan langsung pada orang yang melakukan tindakan tersebut, dan mungkin bahkan melibatkan suatu resiko bagi orang yang menolong. Perilaku prososial merupakan perilaku yang ditujukan demi penigkatan kebaikan orang lain (Ormrod. 2009:132).

Selain itu, Dayakisni (2009: 178) juga menyimpulkan bahwa sikap prososial adalah segala bentuk sikap yang memberikan konsekuensi positif bagi si penerima, baik dalam bentuk materi, fisik ataupun psikologis tetapi tidak memiliki keuntungan yang jelas bagi pemiliknya. Sikap prososial memiliki kategori yang luas mengarah pada sikap yang dinilai positif oleh masyarakat, yang tentu saja berlawanan dengan sikap anti sosial.

Perilaku prososial dipengaruhi oleh tipe hubungan antar orang yaitu karena suka, merasa berkewajiban, memiliki pamrih atau empati. Seseorang biasanya lebih sering membantu orang lain yang di kenal daripada yang tidak di kenal. Meskipun demikan memberikan pertolongan pada orang yang tidak di kenal bukanlah hal yang jarang terjadi. 


\section{METODE PENELITIAN}

Untuk mengumpulkan data yang dapat digunakan sebagai dasar dalam menetapkan tingkat keefektifan, efisensi, atau daya tarik bimbingan kelompok digunakan data prososial siswa yang dapat memberikan informasi perkembangan dan perubahan prososial siswa selama mengikuti tahapan bimbingan kelompok yang didisain untuk meningkatkan prososial siswa. Data ini diperoleh lewat pengamatan oleh observer dan laporan yang dituliskan oleh pemimpin kelompok.

Data-data yang diperlukan dalam penelitian ini diperoleh melalui

1. Observasi

Observasi adalah semua kegiatan yang dilakukan untuk mengamati, merekam, dan mendokumentasikan setiap indikator dari proses dan hasil yang dicapai. Dalam observasi ini peneliti menggunakan (1) Rencana Pelaksanaan Layanan (RPL), dan (2) Penilaian siswa mengikuti layanan bimbingan kelompok. Kedua lembar observasi ini diformat untuk didisi dengan membubuhkan tanda centang $(\sqrt{ })$ pada kolom aspek yang dinilai. Tujuan utama dari observasi ini adalah untuk memantau persiapan, proses, hasil, dan dampak perbaikan dari tindakan setiap siklus.

2. Wawancara

Wawancaraku dilaksanakan selama berlangsungnya PTBK antara peneliti dengan siswa. Hal ini untuk mengetahui pemikiran siswa-siswa yang tidak dapat digali melalui observasi.

3. Studi Dokumenter

Studi dokumenter diartikan sebagai usaha untuk memperoleh data dengan jalan menelaah catatan-catatan yang disimpan sebagai dokumen atau files. Teknik ini ditempuh untuk memperoleh data-data mengenai minat siswa mengikuti pembelajaran.

4. Studi Pustaka

Studi pustaka diartikan sebagai teknik untuk memperoleh data atau informasi dari berbagai tulisan ilmiah baik cetak maupun elektronik yang menunjang penelitian. Teknik ini ditempuh untuk memperoleh pengetahuan yang mendalam mengenai masalah yang diteliti, terutama dalam menentukan arah, metoda dan landasan teoritis penelitian.

Penelitian tindakan kelas terdiri dari 2 siklus merupakan model PTK dari Kemmis dan M. Taggrat.Setiap siklus terdiri dari empat tahapan yaitu perencanaan tindakan (planning), pelaksanaan tindakan (acting), observasing (observing), dan refleksi (reflecting). Namun menurut Saur Tampubolon semua ini diawali dengan refleksi awal atau disebut prapenelitian.

Pada pra siklus dilakukan pree test terlebih dahulu untuk mengetahui data siswa sebelum diterapkan menggunakan model bimbingan kelompok. Prosedur penelitiannya dilakukan secara siklikal. Satu siklus dimulai dari (1) perencanaan awal, (2) pelaksanaan, (3) observasi dan (4) refleksi.

Data yang dianalisis meliputi hal-hal sebagai berikut :

1. Analisis kualitatif dalam penelitian ini menggunakan analisis data selama dilapangan dengan mengumpulkan data secara langsung melalui wawancara atau observasi.

2. Analisis layanan bimbingan kelompok dalam meningkatkan prososial siswa dilakukan dengan menganalisis tingkatan prososial siswa sebelum dan sesudah mengikuti layanan bimbingan kelompok dalam pengujian lapangan. Dengan cara membandingkan antara hasil pre test dan post test. 


\section{HASIL PENELITIAN DAN PEMBAHASAN \\ Siklus I \\ Perencanaan}

a. Terindentifikasi prososial siswa masih rendah.

b. Tersusunnya RPL dengan menggunakan layanan bimbingan kelompok

c. Tersusunnya lembar observasi.

d. Tersusunnya lembar evaluasi.

\section{Tindakan}

Dalam pelaksanaan bimbingan kelompok yang anggota kelompoknya sudah disetting dengan komposisi tertentu.

\section{Hasil Observasi}

Pada siklus I, guru melakukan pengamatan siswa dalam proses bimbingan. Dari hasil pengamatan guru selama proses pembelajaran siklus I diperoleh hasil penilaian prososial siswa pada siklus I lebih meningkat dibandingkan dengan pra siklus. Prososial siswa pada siklus I dari hasil observasi dapat disimpulkan bahwa prososial siswa dengan penggunaan bimbingan kelompok ini ada peningkatan.

\section{Hasil Refleksi}

Setelah dilaksanakan evaluasi pemberian layanan pada siklus I dan pengamatan atas tindakan pemberian layanan yang telah dilakukan, diperoleh data bahwa masih ada beberapa siswa yang prososial nya rendah. Berarti perlu direncanakan perbaikan pemberian layanan siklus 2 .

\section{Siklus 2}

\section{Perencanaan}

Persiapan yang dilakukan untuk pelaksanaan siklus kedua adalah menyiapkan sarana yang akan digunakan sama dengan siklus 1 yaitu RPL, media, lembar observasi dan lembar soal untuk penilaian.

\section{Tindakan}

Dari hasil pemberian layanan pada siklus II menunjukkan adanya peningkatan cukup baik dalam proses layanan maupun setelah pemberian layanan.

\section{Hasil observasi}

Prososial siswa pada siklus II lebih meningkat lagi sangat baik dibandingkan dengan siklus I. Prosossial siswa pada siklus II dari hasil observasi dapat disimpulkan bahwa prososial siswa dengan penggunaan bimbingan kelompok ada peningkatan dari pra siklus kemudian siklus I dan siklus II meningkat.

Selama proses layanan siklus II berlangsung peneliti diamati oleh teman sejawat. Hasil pengamatannya sebagai berikut :

a. Apersepsi dilaksanakan dengan baik.

b. Penguasaan guru terhadap materi baik.

c. Pemberian layanan bimbingan kelompok berhasil dengan baik.

d. Pengelolaan kelompok baik.

e. Keaktifan siswa dalam kegiatan layanan BK cukup baik.

f. Ada keberanian siswa mengeluarkan pendapat. 


\section{Hasil Refleksi}

Berdasarkan hasil refleksi maupun evaluasi pada siklus II ternyata dengan melalui bimbingan kelompok dapat meningkatkan prososial siswa. Hasil refleksi yang diperoleh di lapangan selama pelaksanaan siklus II adalah selama pelaksanaan siklus II, keberanian dan rasa percaya diri siswa benar benar tampak. Sebagian besar siswa, tidak lagi terlihat cuek melainkan mereka peduli terhadap lingkungan sekitar.

\section{PEMBAHASAN}

\section{Siklus I}

Model bimbingan kelompok dirancang untuk kelompok yang beranggotakan 10 orang berdasarkan perspektif bimbingan kelompok bahwa jumlah anggota kelompok yang efektif adalah 10 orang. Keanggotaan bimbingan kelompok yang proses rekruitmentnya secara purposive dengan tujuan tertentu, yaitu merupakan campuran dari individu yang tingkat prososialnya rendah, sedang, dan tinggi menjadikan kelompok ini menjadi yang dinamis.

Percampuran berbagai tingkatan prososial ini menjadikan kehidupan kelompok berkembang ke arah yang positif dan saling memberikan sinergi yang menguntungkan berbagai pihak. Seluruh anggota kelompok berusaha menunjukkan komitmen dan berusaha mengikuti kegiatan dengan sebaik-baiknya. Ada beberapa tahapan yang dilalui dalam tiap kegiatan yaitu tahap pembentukan, tahap peralihan, tahap kegiatan dan tahap pengakhiran.

Berdasarkan hasil pemberian layanan pada siklus I yang oleh peneliti diawali dengan perencaaan dan dilanjutkan dengan tindakan. Peneliti melalui bimbingan kelompok, ternyata hasil yang dicapai dalam bimbingan kelompok pada siklus I, beberapa siswa masih terlihat kurang antusias dan kurang memahami materi yang di berikan dalam layanan. Hal ini disebabkan karena pemahaman siswa terhadap materi layanan masih kurang. Guru dalam memberikan layanan bimbingan kelompok kurang konkret dan terlalu cepat, sehingga hasil yang dicapai belum memuaskan. Dengan demikian perbaikan pemberian layanan bimbingan kelompok siklus I perlu diulang. Tahapan pelaksanaan bimbingan kelompok secara umum terdiri dari empat tahap yaitu pembentukan, peralihan, kegiatan dan pengakhiran. pelaksanaan bimbingan kelompok dilakukan sesuai dengan tahapan namun dalam setiap tahapan tidak diungkapkan secara runtut, misalnya dalam tahap pembentukan langsung dijelaskan cara pelaksanaan bimbingan kelompok yang kemudian dilakukan permainan untuk keakraban dan itupun kadangkala. Pada tahap pengakhiran guru BK tidak memberikan evaluasi terhadap hasil dari topik yang dibahas tetapi langsung mengakhiri kegiatan bimbingan kelompok.

Keterangan diatas dapat diketahui bahwa pemimpin kelompok dalam hal ini guru BK seharusnya memperhatikan tahapan dalam pelaksanaan bimbingan kelompok sesuai dengan teori agar proses bimbingan kelompok dapat berjalan dengan lancar dan memberikan hasil yang diinginkan. Oleh karena itu siswa perlu memperoleh intervensi bimbingan kelompok yang sesuai.

\section{Siklus II}

Bimbingan kelompok memberikan peranan yang signifikan dalam pembentukan prososial siswa. Hal ini dapat dikatakan sebagai nilai positif dari bimbingan kelompok untuk mengembangkan individu menjadi lebih prososial yakni mampu bekerjasama, berbagi dan menolong orang lain. Disamping itu, dengan diterapkannya bimbingan kelompok siswa memiliki kemandirian dalam menyelesaikan masalahnya sendiri, 
menimbulkan rasa saling menghormati orang lain dan dapat saling memberi pengalaman dalam menghadapi dan menyelesaikan masalah. Dengan demikian layanan bimbingan kelompok memiliki nilai yang lebih untuk mengembangkan prososial siswa. Dalam suasana bimbingan kelompok siswa merasa lebih mudah membicarakan persoalan yang mereka hadapi daripada dalam bimbingan individual, lebih mudah menerima sumbangan pikiran dari teman, lebih mudah dan bersedia membuka isi hatinya bila menyaksikan bahwa banyak temannya tidak malu-malu berbicara secara jujur dan terbuka.

Adapun dengan siklus II, siswa mengikuti kegiatan layanan bimbingan kelompok sangat antusias. Pemberian layanan bimbingan kelompok melalui dua siklus ini mengalami perubahan yang berarti. Baik perubahan pada proses layanan maupun setelah pemberian layanan. Siswa dapat lebih tertarik mengikuti layanan bimbingan kelompok, berani mengungkapkan pendapat dan lebih antusias. pelaksanaan bimbingan kelompok dilakukan sesuai dengan tahapan dalam setiap tahapan diungkapkan secara runtut, misalnya dalam tahap pembentukan langsung dijelaskan cara pelaksanaan bimbingan kelompok yang kemudian dilakukan permainan untuk keakraban. Pada tahap pengakhiran guru BK memberikan evaluasi terhadap hasil dari topik yang dibahas kemudian mengakhiri kegiatan bimbingan kelompok. Keterangan diatas dapat diketahui bahwa pemimpin kelompok dalam hal ini guru BK sangat memperhatikan tahapan dalam pelaksanaan bimbingan kelompok sesuai dengan teori sehingga proses bimbingan kelompok dapat berjalan dengan lancar dan memberikan hasil yang diinginkan.

Perubahan tingkat prososial siswa antara pree test dan post test menunjukkan perubahan yang signifikan. Perubahan ini ditandai dengan adanya peningkatan skor baik pada tiap indikator maupun skor total.

\section{DAFTAR PUSTAKA}

Baron Robert A \& Donn Byrne. 2005. Psikologi Sosial. Erlangga. Jakarta

Dayakisni, T.\& Hudaniah. 2009. Psikologi Sosial. Malang: UMM Press

Gibson, Robert L \& Marianne H Mitchell. 2011. Bimbingan dan Konseling. Pustaka Pelajar.Yogyakarta

Johana E. Prawitasari. 2011. Psikologi Klinis. Jakarta. Erlangga.

Narwoko J.Dwi -Bagong Suyanto. 2005. Sosiologi Teks Pengantar dan Terapan. Kencana Prenada Media Group. Jakarta

Ormrod, Jeanne Ellis. 2009. Psikologi Pendidikan Membantu Siswa Tumbuh dan Berkembang. Erlangga. Jakarta.

Prayitno. 2004. Dasar-Dasar Bimbingan Konseling. Jakarta. Rineka Cipta

Prawitasari, Johana E. 2011. Psikologi Klinis Pengantar Terapan Mikro \& Makro. Jakarta: Erlanggga.

Dipublikasikan Oleh: Program Studi Bimbingan dan Konseling 
Romlah, Tatiek. 2001. Teori dan Praktek Bimbingan Kelompok. Malang. Universitas Negeri Malang

Shelley E Taylor, Letitia Anne Peplau, David O Sears. 2009. Psikologi Sosial. Kencana Prenada Media Group. Jakarta.

Sugiyono. 2010. Metode Penelitian Pendidikan. Alfabeta. Bandung

Tohirin. 2008. Bimbingan dan Konseling di Sekolah dan Madrasah (Berbasis Integrasi). PT Rajagrafindo Persada. Jakarta

Wibowo, Mungin Edi. 2005. "Konseling Kelompok Perkembangan". Semarang: UNNES Press.

Wingkel .2004. Bimbingan dan Konseling di Institusi Pendidikan. Jakarta : PT. Gramedia

Winkel, Hastuti. 2010. Bimbingan dan Konseling di Institusi Pendidikan. Yogyakarta: media abadi 